\title{
Influence of initial dose of nitrogen and foliar nutrition on LAI index and infection of fungal pathogens of two morphotypes of field bean
}

\author{
Wpływ dawki startowej azotu oraz dokarmiania dolistnego na wskaźnik LAI \\ oraz porażenie przez patogeny grzybowe dwóch morfotypów bobiku
}

\author{
Wacław Jarecki, Dorota Bobrecka-Jamro
}

\begin{abstract}
Summary
This paper describes the influence of initial dose of nitrogen and foliar nutrition on LAl (leaf area index) index and on infection of fungal pathogens of two morphotypes of faba beans. Occurrence of ascochyta blight (Ascochyta fabae), chocolate spots (Botrytis fabae) and faba bean rust (Uromyces fabae) was analysed. In the years 2011-2013 strict field tests were carried at the Experimental Station of Variety Evaluation in Przecław. The following factors were analysed: initial nitrogen dose $(25 \mathrm{~kg} / \mathrm{ha})$, foliar nutrition (Basfoliar 6-12-6) and Granit and Amulet cultivars. The initial dose of nitrogen considerably increased LAl index in comparison with the control but the foliar nutrition did not influence LAI index as compared with the control. Amulet cultivar was better than Granit cultivar as far as tested parameters were concerned. According to the obtained results fertilization with the initial dose of nitrogen and foliar nutrition did not influence the infection severity of diseases caused by the examined fungal pathogens in respect to the control. On the other hand the cultivars were sensitive to the studied diseases at a different level and it varied in individual years. Granit cultivar as compared with Amulet was infected more by ascochyta blight and chocolate spots and less by faba bean rust.
\end{abstract}

Key words: field bean; Ascochyta fabae; Botrytis fabae; Uromyces fabae; tannins; determinate variety; traditional variety

\section{Streszczenie}

W pracy określono wpływ dawki startowej azotu oraz dokarmiania dolistnego na wskaźnik LAl (leaf area index) oraz porażenie przez grzyby chorobotwórcze dwóch morfotypów bobiku. Ocenie poddano występowanie askochytozy bobiku (Ascochyta fabae), czekoladowej plamistości bobiku (Botrytis fabae) i rdzy bobiku (Uromyces fabae). Ścisłe doświadczenie polowe przeprowadzono w latach 2011-2013 w Stacji Doświadczalnej Oceny Odmian w Przecławiu. Badanymi czynnikami były: dawka startowa azotu (25 kg/ha), dokarmianie dolistne (Basfoliar 6-12-6) oraz odmiany Granit i Amulet. Zastosowana dawka startowa azotu istotnie zwiększyła, natomiast dokarmianie dolistne nie zróżnicowało wskaźnika LAl w porównaniu do obiektu kontrolnego. Odmiana Amulet badanym parametrem przewyższyła odmianę Granit. Uzyskane wyniki badań nie wykazały istotnego wpływu nawożenia startowego azotem, jak i dolistnego dokarmiania na stopień porażenia przez badane patogeny grzybowe w odniesieniu do roślin kontrolnych. Stwierdzono odmianową podatność na oceniane choroby oraz zmienność ich nasilenia w poszczególnych latach. Odmiana Granit w porównaniu do odmiany Amulet była silniej porażona przez A. fabae i B. fabae, a w mniejszym stopniu przez U. fabae.

Słowa kluczowe: bobik; Ascochyta fabae; Botrytis fabae; Uromyces fabae; taniny; odmiana samokończąca; odmiana tradycyjna

Uniwersytet Rzeszowski

Wydział Biologiczno-Rolniczy

Katedra Produkcji Roślinnej

Zelwerowicza 4, 35-601 Rzeszów

waclaw.jarecki@wp.pl 


\section{Wstęp / Introduction}

Stopień i nasilenie porażenia roślin bobowatych przez patogeny zależy od wielu czynników, m.in.: warunków pogodowych, zabiegów agrotechnicznych (Kurowski i wsp. 2006), odmiany, zainfekowania gleby i otoczenia plantacji oraz zdrowotności materiału siewnego. HoroszkiewiczJanka i wsp. (2013) podają, że wysokość strat w plonach bobowatych spowodowanych występowaniem chorób szacuje się średnio na $15 \%$, ale mogą wynieść nawet $80 \%$.

Do ważniejszych chorób bobiku należą askochytoza bobiku i czekoladowa plamistość bobiku, natomiast rdza bobiku jest groźniejsza dla odmian później dojrzewających. Zwalczanie chorób w czasie wegetacji polega zwykle na zastosowaniu środków chemicznych, przy czym liczba zarejestrowanych fungicydów dla bobiku w ostatnich latach znacząco spadła. W efekcie tego możliwości chemicznego zwalczania niektórych chorób zostały ograniczone (Horoszkiewicz-Janka i wsp. 2013). Fernández-Aparicio i wsp. (2011) za korzystną w tej sytuacji uważają szerszą uprawę mieszanek strączkowo-zbożowych. Potwierdzają to wyniki ich doświadczeń w różnych warunkach siedliskowych. Z badań Kuliga i wsp. (2006) wynika, że dwukrotne stosowanie fungicydów powoduje przeciętny przyrost plonu nasion bobiku o 5,6\% w odniesieniu do kontroli, przy czym efektywność stosowanych zabiegów ochrony roślin była większa u odmiany tradycyjnej. Księżak i Kuś (2005) stosując ochronę przed chorobami i szkodnikami w konwencjonalnej uprawie bobiku uzyskali wyraźnie wyższy plon nasion i wzrost komponentów plonu. Kulig i wsp. (2009) wskazali na mniejszą skuteczność ekologicznych środków ochrony roślin w porównaniu do syntetycznych. Kolasińska i Wiewióra (2002) oraz Dłużniewska i wsp. (2007) stwierdzili podobną podatność na choroby nisko- i wysokotaninowych form bobiku. Kolasińska i Wiewióra (2002) potwierdziły jednak niższą zdrowotność i odporność na warunki środowiska nasion odmiany niskotaninowej. Dłużniewska i wsp. (2010) za bardzo ważne w tym aspekcie wskazują badania nad przyczynami występowania i nasilenia chorób powodowanych przez grzyby oraz odpornością na czynniki stresowe u bobiku. Roślina ta $\mathrm{w}$ uprawie na nasiona posiada wysoką zdolność plonotwórczą, przy czym zmienną w latach (Kulig i Zając 2007; Stępnik i Le-piarczyk 2009; Jerzak i wsp. 2012). Ze względu na dużą zawartość białka jest zarazem szczególnie podatna na porażenie przez grzyby chorobotwórcze. Efektem ich występowania są straty w plonach, w tym zmniejszenie jakości uzyskanych nasion (Księżak i Kuś 2005; Kurowski i wsp. 2006).

Księżak (2007) największą akumulację azotu w roślinach bobiku uzyskał od końca kwitnienia do dojrzałości strąków. W fazie początku kwitnienia roślin stwierdził znacznie większy udział liści w całkowitej ilości azotu akumulowanego, natomiast w roślinach dojrzałych najwięcej azotu było w strąkach. Prusiński (2007) wykazał, że nawożenie azotem bobiku modyfikuje zawartość azotu w roślinach przy czym jest to uzależnione od dawki i sposobu zastosowania azotu (doglebowo lub dolistnie).
Celem badań było określenie wpływu dawki startowej azotu oraz dokarmiania dolistnego (Basfoliar 6-12-6) na wskaźnik LAI (leaf area index) oraz porażenie dwóch odmian bobiku przez patogeny powodujące askochytozę bobiku, czekoladową plamistość bobiku i rdzę bobiku. W hipotezie badawczej założono, że nawożenie azotem lub dolistne dokarmianie będą mieć wpływ na wskaźnik LAI i stopień nasilenia chorób grzybowych bobiku.

\section{Materiały i metody / Materials and methods}

Ścisłe doświadczenie polowe przeprowadzone zostało w latach 2011-2013 na polu Stacji Doświadczalnej Oceny Odmian w Przecławiu. Był to eksperyment trzyczynnikowy w układzie split-split-plot, w czterech powtórzeniach. Badanymi czynnikami były:

1. Dawka startowa azotu $(25 \mathrm{~kg} / \mathrm{ha})$ i kontrola - bez dawki startowej.

2. Odmiany: Amulet i Granit.

3. Dokarmianie dolistne (Basfoliar 6-12-6) i kontrola bez dokarmiania dolistnego.

Gleba, na której założono doświadczenie, należała do kompleksu pszennego bardzo dobrego. Jej zasobność w przyswajalny fosfor i potas była średnia, a odczyn lekko kwaśny. Nasiona do siewu pochodziły z firmy Hodowla Roślin Strzelce Sp. z o.o., grupa IHAR, które zaprawiono zaprawą Sarfun T 65 DS oraz bezpośrednio przed siewem nitraginą. Rozstawa rzędów wynosiła $25 \mathrm{~cm}$, zaś głębokość siewu $8 \mathrm{~cm}$. Siew wykonano w trzeciej dekadzie marca lub pierwszej kwietnia. Powierzchnia poletek wynosiła 19,5 $\mathrm{m}^{2}$ (do zbioru 16,5 $\mathrm{m}^{2}$ ). Corocznie, przedplonem była pszenica ozima. Zabiegi agrotechniczne zostały przeprowadzone zgodnie z metodyką Centralnego Ośrodka Badania Odmian Roślin Uprawnych (COBORU) z uwzględnieniem różnic w normie wysiewu dla odmiany tradycyjnej i samokończącej. Nawożenie fosforowo-potasowe zastosowano jesienią $\mathrm{w}$ formie superfosfatu potrójnego granulowanego oraz soli potasowej i wyniosło: $70 \mathrm{~kg} / \mathrm{ha} \mathrm{P}_{2} \mathrm{O}_{5}$ i $120 \mathrm{~kg} / \mathrm{ha} \mathrm{K}_{2} \mathrm{O}$. Dokarmianie dolistne przeprowadzono dwukrotnie, tj. przed i po kwitnieniu roślin $(2 \times 10 \mathrm{l} / \mathrm{ha})$. Do zwalczania chwastów wykorzystano Linurex 500 SC bezpośrednio po siewie ( 2 1/ha). Zachwaszczenie wtórne (niewielkie) usunięto ręcznie. Szkodniki zwalczano dwukrotnie przy użyciu Karate Zeon 050 EC (0,15 1/ha) oraz jednorazowo przy użyciu preparatu Pirimor $500 \mathrm{WG}$ $(0,3 \mathrm{~kg} / \mathrm{ha})$. Przeciw chorobom zastosowano dwukrotnie Rovral Aquaflo $500 \mathrm{SC}$ (iprodion) w dawce 1,5 kg/ha. $\mathrm{Z}$ uwagi na występowanie grzybów chorobotwórczych dokonano oceny występowania: askochytozy bobiku (Ascochyta fabae), czekoladowej plamistości bobiku (Botrytis fabae) oraz rdzy bobiku (Uromyces fabae). W każdym sezonie wegetacyjnym ocenę stanu zdrowotności roślin przeprowadzono w momencie najsilniejszego porażenia bobiku. Na poletku przebadano losowo 30 roślin stosując pięciostopniową skalę, tj.: 0 - zdrowe, 1 - (1-10\%), 2 (11-30\%), 3 - (31-60\%), 4 - (61 i więcej \%). Po dokonanej ocenie chorób bobiku obliczono indeks porażenia wykorzystując zmodyfikowany wzór Townsenda-Heubergera z pracy Kuliga i wsp. (2006) 


$$
\mathrm{Ip}=\frac{\sum(\mathrm{a} \times \mathrm{b}) \times 100}{\mathrm{~N} \times \mathrm{n}}
$$

Ip - indeks porażenia

a - liczba zbadanych roślin

$\mathrm{b}$ - stopień porażenia

$\mathrm{N}$ - ogólna liczba przebadanych roślin

$\mathrm{n}$ - największy stopień porażenia zastosowany w skali

Stosunek powierzchni asymilacyjnej łanu bobiku do powierzchni pola (wskaźnik LAI)) wyznaczono miernikiem LAI 2000 firmy Li-Cor w fazie pierwszego płaskiego strąka w godzinach przedpołudniowych.

Do opracowania uzyskanych wyników wybrano analizę wariancji. Istotność różnic między wartościami cech stwierdzono na podstawie półprzedziałów ufności Tuckeya, przy poziomie istotności $\alpha=0,05$. Obliczenia wykonano programem statystycznym FR-ANALWAR-5FR. Warunki pogodowe podano według zapisów Stacji Doświadczalnej Oceny Odmian w Przecławiu. Analiza próbek glebowych została wykonana w Okręgowej Stacji Chemiczno-Rolniczej w Rzeszowie.

\section{Wyniki i dyskusja / Results and discussion}

Warunki pogodowe w latach prowadzenia badań były zróżnicowane (tab. 1). W 2012 roku w okresie marzec- sierpień odnotowano mniejszą sumę opadów w porównaniu do lat 2011 i 2013. Intensywny opad deszczu wystąpił w lipcu 2011 roku oraz maju i czerwcu 2013 roku. W marcu 2013 roku odnotowano ujemną miesięczną temperaturę powietrza. Do najcieplejszych miesięcy należały sierpień w 2011 r. oraz lipiec w 2012 r. i 2013 r. Podleśny (2006, 2009) stwierdza, że układ warunków pogodowych bardzo wyraźnie modyfikuje wzrost, rozwój i plonowanie bobiku. Spadek plonu notował zwłaszcza w latach o długotrwałych okresach suszy wiosenno-letniej.

Warunki wilgotnościowo-termiczne wywarły istotny wpływ na występowanie i nasilenie chorób grzybowych bobiku: askochytozy bobiku, czekoladowej plamistości bobiku i rdzy bobiku. Silniejsze porażenie roślin przez patogeny powodujące czekoladową plamistość i askochytozę wystąpiło w latach wilgotnych i ciepłych, tj. 2011 i 2013. Rdzę bobiku w najmniejszym nasileniu odnotowano w 2011 roku. Księżak i Kuś (2005) zaobserwowali, niezależnie od przebiegu pogody, niewielkie zróżnicowanie chorób w poszczególnych sezonach wegetacyjnych. W badaniach Kuliga i wsp. (2007) nadmiar opadów w okresie wschodów przyczynił się do porażenia systemu korzeniowego siewek kompleksem patogenów grzybowych i wypadaniem roślin z łanu. Kurowski i wsp. (2006) najwyższą zdrowotność bobiku stwierdził w płodozmianie norfolskim. Choroby liści w badaniach tych autorów w największym nasileniu wystąpiły, gdy bobik miał $50 \%$ udział w płodozmianie.

Tabela 1. Warunki pogodowe w latach 2011-2013

Table 1. Weather conditions in the years 2011-2013

\begin{tabular}{l|c|c|c|c|c|c}
\hline \multirow{2}{*}{ Miesiące - Months } & \multicolumn{3}{|c|}{ Opady - Rainfall [mm] } & \multicolumn{3}{c}{ Średnie temperatury - Average temperatures [ $\left.{ }^{\circ} \mathrm{C}\right]$} \\
\cline { 2 - 7 } & 2011 & 2012 & 2013 & 2011 & 2012 & 2013 \\
\hline Marzec - March & 12,5 & 27,8 & 73,6 & 2,80 & 3,93 & $-1,25$ \\
\hline Kwiecień - April & 52,3 & 21,7 & 40,4 & 10,00 & 14,89 & 8,84 \\
\hline Maj - May & 38,1 & 66,7 & 111,7 & 13,80 & 18,24 & 15,00 \\
\hline Czerwiec - June & 78,6 & 66,9 & 192,4 & 18,10 & 20,87 & 18,52 \\
\hline Lipiec - July & 291,8 & 65,6 & 58,3 & 18,50 & 18,75 & 18,36 \\
\hline Sierpień - August & 58,6 & 61,8 & 21,2 & 19,10 & \\
\hline
\end{tabular}

Tabela 2. Wpływ badanych czynników na index LAI $\left[\mathrm{m}^{2} / \mathrm{m}^{2}\right]$

Table 2. The effect of studied factors on the index LAI $\left[\mathrm{m}^{2} / \mathrm{m}^{2}\right]$

\begin{tabular}{|c|c|c|c|c|c|c|}
\hline $\begin{array}{l}\text { Dawka startowa azotu } \\
\text { Initial fertilizing }\end{array}$ & $\begin{array}{l}\text { Odmiana } \\
\text { Cultivar }\end{array}$ & $\begin{array}{l}\text { Dokarmianie dolistne } \\
\text { Foliar fertilization }\end{array}$ & 2011 & 2012 & 2013 & $\begin{array}{c}\text { Średnia } \\
\text { Mean }\end{array}$ \\
\hline 1 & 2 & 3 & 4 & 5 & 6 & 7 \\
\hline \multirow{4}{*}{$\begin{array}{l}\text { Kontrola - bez dawki startowej } \\
\text { Control - without initial fertilizing }\end{array}$} & \multirow[t]{2}{*}{ Amulet } & $\begin{array}{l}\text { kontrola - bez dokarmiania dolistnego } \\
\text { control - without foliar fertilization }\end{array}$ & 3,93 & 3,94 & 4,12 & 4,00 \\
\hline & & Basfoliar 6-12-6 & 3,91 & 3,87 & 4,20 & 3,99 \\
\hline & \multirow[t]{2}{*}{ Granit } & $\begin{array}{l}\text { kontrola - bez dokarmiania dolistnego } \\
\text { control - without foliar fertilization }\end{array}$ & 3,74 & 3,65 & 3,29 & 3,56 \\
\hline & & Basfoliar 6-12-6 & 3,65 & 3,65 & 3,91 & 3,73 \\
\hline \multirow{4}{*}{$25 \mathrm{~N} \mathrm{~kg} / \mathrm{ha}$} & \multirow[t]{2}{*}{ Amulet } & $\begin{array}{l}\text { kontrola - bez dokarmiania dolistnego } \\
\text { control - without foliar fertilization }\end{array}$ & 4,20 & 4,19 & 4,69 & 4,36 \\
\hline & & Basfoliar 6-12-6 & 3,91 & 3,96 & 4,79 & 4,22 \\
\hline & \multirow[t]{2}{*}{ Granit } & $\begin{array}{l}\text { kontrola - bez dokarmiania dolistnego } \\
\text { control - without foliar fertilization }\end{array}$ & 4,04 & 4,05 & 3,51 & 3,87 \\
\hline & & Basfoliar 6-12-6 & 3,90 & 3,81 & 3,87 & 3,86 \\
\hline
\end{tabular}




\begin{tabular}{|c|c|c|c|c|c|}
\hline 1 & 2 & 4 & 5 & 6 & 7 \\
\hline \multicolumn{6}{|c|}{ Średnie dla czynników - The average for the studied factors } \\
\hline \multicolumn{2}{|c|}{ Kontrola - bez dawki startowej - Control - without initial fertilizing } & 3,80 & 3,78 & 3,88 & 3,82 \\
\hline \multicolumn{2}{|l|}{$25 \mathrm{~N} \mathrm{~kg} / \mathrm{ha}$} & 4,01 & 4,00 & 4,21 & 4,08 \\
\hline \multicolumn{2}{|l|}{$\operatorname{NIR}(0,05)-\operatorname{LSD}(0.05) \mathrm{A}$} & r.n. & r.n. & 0,295 & 0,208 \\
\hline \multicolumn{2}{|l|}{ Amulet } & 3,99 & 3,99 & 4,45 & 4,14 \\
\hline \multicolumn{2}{|l|}{ Granit } & 3,83 & 3,79 & 3,64 & 3,75 \\
\hline \multicolumn{2}{|l|}{ NIR $(0,05)-\operatorname{LSD}(0.05) \mathrm{B}$} & r.n. & r.n. & 0,640 & 0,291 \\
\hline \multicolumn{2}{|c|}{ Kontrola - bez dokarmiania dolistnego - Control - without foliar fertilization } & 3,98 & 3,96 & 3,90 & 3,95 \\
\hline \multicolumn{2}{|l|}{ Basfoliar 6-12-6 } & 3,84 & 3,82 & 4,19 & 3,95 \\
\hline \multicolumn{2}{|l|}{$\operatorname{NIR}(0,05)-\operatorname{LSD}(0.05) \mathrm{C}$} & r.n. & r.n. & r.n. & r.n. \\
\hline \multicolumn{2}{|l|}{ Średnia ogólna - Average total } & 3,91 & 3,88 & 4,05 & 3,95 \\
\hline \multicolumn{2}{|c|}{ NIR $(0,05)$ - LSD $(0.05)$ lata - year } & \multicolumn{4}{|c|}{ r.n. } \\
\hline
\end{tabular}

r.n. - różnica nieistotna - not significant difference

LAI - leaf area index

Zastosowana dawka startowa azotu istotnie zwiększyła wskaźnik LAI w porównaniu do roślin kontrolnych. Było to jednak zmienne w latach. Odmiana Amulet badanym parametrem przewyższyła odmianę Granit, pomimo że odmiana tradycyjna była wysiana rzadziej niż odmiana samokończąca. Dokarmianie dolistne nie wywarło modyfikującego wpływu na wskaźnik LAI. Średnio wskaźnik LAI wyniósł 3,95 m²/m² (tab. 2). Kulig i wsp. (2007, 2012) podają, że wielkość powierzchni asymilacyjnej w dużym stopniu decyduje o wykorzystaniu promieniowania fotosyntetycznego czynnego i wonsekwencji o produkcji biomasy. Wspomniani autorzy maksymalną wielkość wskaźnika LAI uzyskali pod koniec fazy kwitnienia przy znaczących jego wahaniach w latach badań. Stwierdzili też istotne różnice odmianowe. Odmiany wysokotaninowe w ich doświadczeniu miały większą średnią wartość wskaźnika LAI niż odmiany o obniżonej zawartości tanin. Podleśny (2006) wysiewając bobik punktowo uzyskał większą powierzchnię liściową roślin niż z siewu niepunktowego. Prusiński i wsp. (2008) stwierdzili, że wysokie wartości wskaźnika LAI zmierzone pod koniec fazy kwitnienia nie są miarodajne do prognozowania wysokości plonu końcowego biomasy bobiku ani udziału w nim plonu nasion.

Askochytoza bobiku rozwijała się we wszystkich latach badań (tab. 3). Jej nasilenie było największe w 2013 r., zaś najmniejsze w 2012 r. Dawka startowa azotu i dokarmianie dolistne nie wywarło istotnego wpływu na stopień porażenia patogenem. Stwierdzono, że odmiana Granit jest silniej atakowana przez askochytozę bobiku w porównaniu do odmiany Amulet. Zależność tę notowano w każdym roku prowadzonych badań. Dłużniewska i wsp. (2007) nie wykazali jednoznacznie, że zdrowotność roślin niskotaninowych jest słabsza niż wysokotaninowych. Dodatkowo Dłużniewska i wsp. (2008) stwierdzili, że ochrona fungicydowa przed chorobami wywołującymi plamistości na roślinach bobiku nie zawsze powoduje wzrost ich zdrowotności, jest to bowiem uzależnione od odmiany i roku badań.

Tabela 3. Wpływ badanych czynników na wystepowanie askochytozy bobiku (indeks porażenia)

Table 3. The effect of studied factors on the infection with ascochyta blight (infection index)

\begin{tabular}{|c|c|c|c|c|c|c|}
\hline $\begin{array}{l}\text { Dawka startowa azotu } \\
\text { Initial fertilizing }\end{array}$ & $\begin{array}{l}\text { Odmiana } \\
\text { Cultivar }\end{array}$ & $\begin{array}{l}\text { Dokarmianie dolistne } \\
\text { Foliar fertilization }\end{array}$ & 2011 & 2012 & 2013 & $\begin{array}{c}\text { Średnia } \\
\text { Mean }\end{array}$ \\
\hline 1 & 2 & 3 & 4 & 5 & 6 & 7 \\
\hline \multirow{4}{*}{$\begin{array}{l}\text { Kontrola - bez dawki startowej } \\
\text { Control - without initial } \\
\text { fertilizing }\end{array}$} & \multirow[t]{2}{*}{ Amulet } & $\begin{array}{l}\text { kontrola - bez dokarmiania dolistnego } \\
\text { control - without foliar fertilization }\end{array}$ & 16,7 & 16,7 & 31,7 & 21,7 \\
\hline & & Basfoliar 6-12-6 & 16,7 & 16,7 & 27,5 & 20,3 \\
\hline & \multirow[t]{2}{*}{ Granit } & $\begin{array}{l}\text { kontrola - bez dokarmiania dolistnego } \\
\text { control - without foliar fertilization }\end{array}$ & 37,5 & 25,0 & 40,0 & 34,2 \\
\hline & & Basfoliar 6-12-6 & 37,5 & 25,0 & 44,2 & 35,6 \\
\hline \multirow{4}{*}{$25 \mathrm{~N} \mathrm{~kg} / \mathrm{ha}$} & \multirow[t]{2}{*}{ Amulet } & $\begin{array}{l}\text { kontrola - bez dokarmiania dolistnego } \\
\text { control - without foliar fertilization }\end{array}$ & 16,7 & 16,7 & 27,5 & 20,3 \\
\hline & & Basfoliar 6-12-6 & 16,7 & 16,7 & 31,7 & 21,7 \\
\hline & \multirow[t]{2}{*}{ Granit } & $\begin{array}{l}\text { kontrola - bez dokarmiania dolistnego } \\
\text { control - without foliar fertilization }\end{array}$ & 41,7 & 25,0 & 35,8 & 34,2 \\
\hline & & Basfoliar 6-12-6 & 41,7 & 25,0 & 44,2 & 37,0 \\
\hline
\end{tabular}




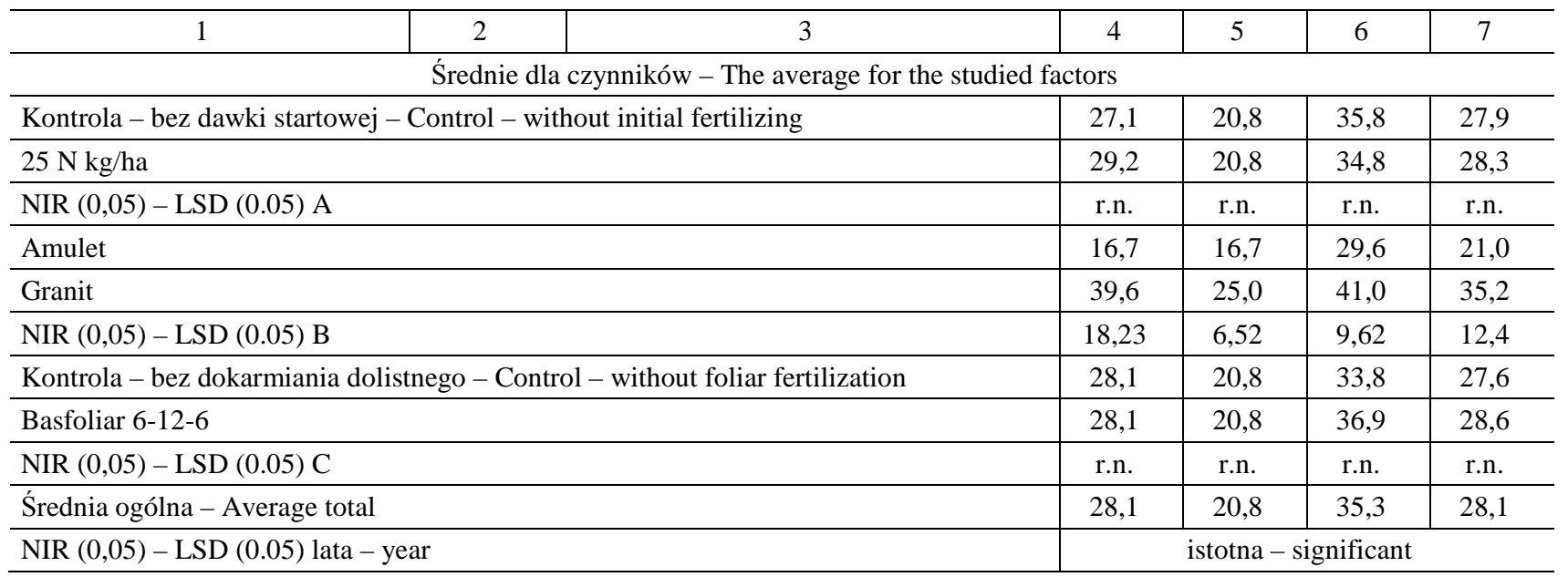

r.n. - różnica nieistotna - not significant difference

Porażenie roślin przez grzyby wywołujące czekoladową plamistość bobiku było zróżnicowane w latach badań (tab. 4). Najsilniejsze odnotowano w 2013 r., zaś najmniejsze w 2012 r. Indeks porażenia nie został istotnie zmodyfikowany dawką startową azotu ani dokarmianiem dolistnym. Na roślinach odmiany Granit stwierdzono silniejsze wystąpienie czekoladowej plamistości bobiku w porównaniu do roślin odmiany Amulet. Jedynie w 2013 r. zależności tej nie udowodniono statystycznie. Dłużniewska i wsp. (2010) wykazali, że niskotaninowa tradycyjna odmiana bobiku (Olga) była w mniejszym stopniu opanowana przez czekoladową plamistość niż odmiana wysokotaninowa samokończąca (Optimal). Marks i wsp. (2004) czekoladową plamistość i inne plamistości liści uznali za groźne choroby bobiku, zwłaszcza w wilgotnych i ciepłych sezonach wegetacyjnych. Księżak i Kuś (2005) oraz Kulig i wsp. (2006) za celowe uznali stosowanie zabiegów ochrony roślin w bobiku, w tym przeciw chorobom. Po zastosowaniu fungicydów w prowadzonych doświadczeniach uzyskiwali bowiem istotny efekt plonochronny.

Tabela 4. Wpływ badanych czynników na występowanie czekoladowej plamistości bobiku (indeks porażenia)

Table 4. The effect of studied factors on the infection with chocolate spot (infection index)

\begin{tabular}{|c|c|c|c|c|c|c|}
\hline $\begin{array}{l}\text { Dawka startowa azotu } \\
\text { Initial fertilizing }\end{array}$ & $\begin{array}{l}\text { Odmiana } \\
\text { Cultivar }\end{array}$ & $\begin{array}{l}\text { Dokarmianie dolistne } \\
\text { Foliar fertilization }\end{array}$ & 2011 & 2012 & 2013 & $\begin{array}{c}\text { Średnia } \\
\text { Mean }\end{array}$ \\
\hline \multirow{4}{*}{$\begin{array}{l}\text { Kontrola - bez dawki startowej } \\
\text { Control - without initial } \\
\text { fertilizing }\end{array}$} & \multirow[t]{2}{*}{ Amulet } & $\begin{array}{l}\text { kontrola - bez dokarmiania dolistnego } \\
\text { control - without foliar fertilization }\end{array}$ & 42,2 & 23,8 & 45,8 & 37,2 \\
\hline & & Basfoliar 6-12-6 & 38,5 & 22,0 & 44,0 & 34,8 \\
\hline & \multirow[t]{2}{*}{ Granit } & $\begin{array}{l}\text { kontrola - bez dokarmiania dolistnego } \\
\text { control - without foliar fertilization }\end{array}$ & 38,5 & 18,3 & 47,7 & 34,8 \\
\hline & & Basfoliar 6-12-6 & 36,7 & 20,2 & 45,8 & 34,3 \\
\hline \multirow{4}{*}{$25 \mathrm{~N} \mathrm{~kg} / \mathrm{ha}$} & \multirow[t]{2}{*}{ Amulet } & $\begin{array}{l}\text { kontrola - bez dokarmiania dolistnego } \\
\text { control - without foliar fertilization }\end{array}$ & 40,3 & 23,8 & 45,8 & 36,7 \\
\hline & & Basfoliar 6-12-6 & 42,2 & 23,8 & 45,8 & 37,2 \\
\hline & \multirow[t]{2}{*}{ Granit } & $\begin{array}{l}\text { kontrola - bez dokarmiania dolistnego } \\
\text { control - without foliar fertilization }\end{array}$ & 36,7 & 18,3 & 47,7 & 34,3 \\
\hline & & Basfoliar 6-12-6 & 36,7 & 18,3 & 47,7 & 34,3 \\
\hline \multicolumn{7}{|c|}{ Średnie dla czynników - The average for the studied factors } \\
\hline \multicolumn{3}{|c|}{ Kontrola - bez dawki startowej - Control - without initial fertilizing } & 39,0 & 21,1 & 45,8 & 35,3 \\
\hline \multicolumn{3}{|l|}{$25 \mathrm{~N} \mathrm{~kg} / \mathrm{ha}$} & 39,0 & 21,1 & 46,8 & 35,6 \\
\hline \multicolumn{3}{|l|}{$\operatorname{NIR}(0,05)-\operatorname{LSD}(0.05) \mathrm{A}$} & r.n. & r.n. & r.n. & r.n. \\
\hline \multicolumn{3}{|l|}{ Amulet } & 37,1 & 18,8 & 47,2 & 34,4 \\
\hline \multicolumn{3}{|l|}{ Granit } & 40,8 & 23,4 & 45,4 & 36,5 \\
\hline \multicolumn{3}{|l|}{ NIR $(0,05)-\operatorname{LSD}(0.05) \mathrm{B}$} & 2,85 & 3,58 & r.n. & 1,86 \\
\hline \multicolumn{3}{|c|}{ Kontrola - bez dokarmiania dolistnego - Control - without foliar fertilization } & 39,4 & 21,1 & 46,8 & 35,8 \\
\hline \multicolumn{3}{|l|}{ Basfoliar 6-12-6 } & 38,5 & 21,1 & 45,8 & 35,2 \\
\hline \multicolumn{3}{|l|}{$\operatorname{NIR}(0,05)-\operatorname{LSD}(0.05) \mathrm{C}$} & r.n. & r.n. & r.n. & r.n. \\
\hline \multicolumn{3}{|l|}{ Średnia ogólna - Average total } & 39,0 & 21,1 & 46,3 & 35,5 \\
\hline \multicolumn{3}{|l|}{ NIR $(0,05)$ - LSD $(0.05)$ lata - year } & \multicolumn{4}{|c|}{ istotna - significant } \\
\hline
\end{tabular}


Tabela 5. Wpływ badanych czynników na nasilenie rdzy bobiku (indeks porażenia)

Table 5. The effect of studied factors on the infection with rust of field bean (infection index)

\begin{tabular}{|c|c|c|c|c|c|c|}
\hline $\begin{array}{l}\text { Dawka startowa azotu } \\
\text { Initial fertilizing }\end{array}$ & $\begin{array}{l}\text { Odmiana } \\
\text { Cultivar }\end{array}$ & $\begin{array}{l}\text { Dokarmianie dolistne } \\
\text { Foliar fertilization }\end{array}$ & 2011 & 2012 & 2013 & $\begin{array}{l}\text { Średnia } \\
\text { Mean }\end{array}$ \\
\hline \multirow{4}{*}{$\begin{array}{l}\text { Kontrola - bez dawki startowej } \\
\text { Control - without initial } \\
\text { fertilizing }\end{array}$} & \multirow[t]{2}{*}{ Amulet } & $\begin{array}{l}\text { kontrola - bez dokarmiania dolistnego } \\
\text { control - without foliar fertilization }\end{array}$ & 19,5 & 22,5 & 33,5 & 25,2 \\
\hline & & Basfoliar 6-12-6 & 19,5 & 21,0 & 33,5 & 24,7 \\
\hline & \multirow[t]{2}{*}{ Granit } & $\begin{array}{l}\text { kontrola - bez dokarmiania dolistnego } \\
\text { control - without foliar fertilization }\end{array}$ & 15,0 & 15,0 & 33,5 & 21,2 \\
\hline & & Basfoliar 6-12-6 & 15,0 & 18,0 & 32,0 & 21,7 \\
\hline \multirow{4}{*}{$25 \mathrm{~N} \mathrm{~kg} / \mathrm{ha}$} & \multirow[t]{2}{*}{ Amulet } & $\begin{array}{l}\text { kontrola - bez dokarmiania dolistnego } \\
\text { control - without foliar fertilization }\end{array}$ & 19,5 & 22,5 & 33,5 & 25,2 \\
\hline & & Basfoliar 6-12-6 & 19,5 & 21,0 & 35,0 & 25,2 \\
\hline & \multirow[t]{2}{*}{ Granit } & $\begin{array}{l}\text { kontrola - bez dokarmiania dolistnego } \\
\text { control - without foliar fertilization }\end{array}$ & 15,0 & 16,5 & 35,0 & 22,2 \\
\hline & & Basfoliar 6-12-6 & 15,0 & 16,5 & 32,0 & 21,2 \\
\hline \multicolumn{7}{|c|}{ Średnie dla czynników - The average for the studied factors } \\
\hline \multicolumn{3}{|c|}{ Kontrola - bez dawki startowej - Control - without initial fertilizing } & 17,3 & 19,1 & 33,1 & 23,2 \\
\hline \multicolumn{3}{|l|}{$25 \mathrm{~N} \mathrm{~kg} / \mathrm{ha}$} & 17,3 & 19,1 & 33,9 & 23,4 \\
\hline \multicolumn{3}{|l|}{$\operatorname{NIR}(0,05)-\operatorname{LSD}(0.05) \mathrm{A}$} & r.n. & r.n. & r.n. & r.n. \\
\hline \multicolumn{3}{|l|}{ Amulet } & 19,5 & 21,8 & 33,9 & 25,0 \\
\hline \multicolumn{3}{|l|}{ Granit } & 15,0 & 16,5 & 33,1 & 21,5 \\
\hline \multicolumn{3}{|l|}{$\operatorname{NIR}(0,05)-\operatorname{LSD}(0.05) \mathrm{B}$} & 3,82 & 4,67 & r.n. & 2,86 \\
\hline \multicolumn{3}{|c|}{ Kontrola - bez dokarmiania dolistnego - Control - without foliar fertilization } & 17,3 & 19,1 & 33,9 & 23,4 \\
\hline \multicolumn{3}{|l|}{ Basfoliar 6-12-6 } & 17,3 & 19,1 & 33,1 & 23,2 \\
\hline \multicolumn{3}{|l|}{$\operatorname{NIR}(0,05)-\operatorname{LSD}(0.05) \mathrm{C}$} & r.n. & r.n. & r.n. & r.n. \\
\hline \multicolumn{3}{|l|}{ Średnia ogólna - Average total } & 17,3 & 19,1 & 33,5 & 23,3 \\
\hline \multicolumn{3}{|l|}{ NIR $(0,05)$ - LSD $(0.05)$ lata - year } & \multicolumn{4}{|c|}{ istotna - significant } \\
\hline
\end{tabular}

Zainfekowanie roślin przez grzyby powodujące rdzę bobiku było największe $\mathrm{w}$ trzecim roku badań (tab. 5). Zarówno dawka startowa azotu, jak i zastosowany Basfoliar 6-12-6 nie wpłynęły istotnie na obliczony indeks porażenia roślin przez tego patogena. Udowodniono natomiast, że odmiana Amulet jest silniej atakowana przez rdzę bobiku w porównaniu do odmiany Granit. Zależność tę potwierdzano corocznie. W badaniach COBORU (2013) przeprowadzonych w 2012 r. różnice w nasileniu rdzy bobiku na odmianie Amulet i Granit były podobne.

\section{Wnioski / Conclusions}

1. Zastosowana dawka startowa azotu istotnie zwiększyła wskaźnik LAI, a dokarmianie dolistne nie wywarło wpływu na ten wskaźnik w porównaniu do roślin kontrolnych. Odmiana Amulet wartością wskaźnika LAI przewyższyła odmianę Granit.
2. Uzyskane wyniki badań nie wykazały istotnego wpływu nawożenia startowego azotem i dolistnego dokarmiania na stopień porażenia roślin przez wybrane patogeny grzybowe.

3. Stwierdzono różnice $\mathrm{w}$ odporności badanych odmian na oceniane choroby oraz zmienność ich nasilenia w poszczególnych latach. Odmiana Granit w porównaniu do odmiany Amulet była silniej porażona przez patogeny powodujące askochytozę bobiku i czekoladową plamistość bobiku, zaś w mniejszym stopniu przez rdzę bobiku.

4. Największy indeks porażenia odnotowano w 2013 roku. Wystąpiły wówczas intensywne opady deszczu w maju i czerwcu przy wysokich średnich miesięcznych temperaturach.

Badania prowadzono $\mathrm{w}$ ramach projektu badawczego własnego Narodowego Centrum Nauki, N N310 003040.

\section{Literatura / References}

Dłużniewska J., Nadolnik M., Kulig B. 2007. Wpływ ochrony chemicznej na stan zdrowotny niskotaninowych odmian bobiku (Vicia $f a b a$ L.). [The efect of chemical control on healthiness of low tannin faba bean (Vicia faba L.) varietes]. Prog. Plant Prot./Post. Ochr. Roślin 47 (2): 81-84. 
Dłużniewska J., Nadolnik M., Kulig B. 2008. Porównanie wpływu ochrony środkami konwencjonalnymi z ochroną środkami w rolnictwie ekologicznym na zdrowotność bobiku (Vicia faba L.). [The effect of conventional and organic pesticides on healthiness of faba bean (Vicia faba L.)]. Prog. Plant Prot./Post. Ochr. Roślin 48 (2): 706-709.

Dłużniewska J., Nadolnik M., Kulig B. 2010. Choroby bobiku uprawianego z owsem z różnym udziałem komponentów w mieszance. [Diseases of faba bean in mixed cropping with oat]. Prog. Plant Prot./Post. Ochr. Roślin 50 (4): 1789-1792.

Domański P.J., Osiecka A., Paczocha J. 2013. Lista opisowa odmian. Rośliny rolnicze. Bobik. COBORU, Słupia Wielka: 118-119.

Fernández-Aparicio M., Shtaya M.J.Y., Emeran A.A., Allagui M.B., Kharrat M., Rubiales D. 2011. Effects of crop mixtures on chocolate spot development on faba bean grown in mediterranean climates. Crop Prot. 30 (8): 1015-1023.

Horoszkiewicz-Janka J., Jajor E., Korbas M. 2013. Zagrożenie roślin strączkowych (bobowatych) przez grzyby chorobotwórcze i możliwości ich zwalczania. [Potential risk of infection of pathogenic fungi to legumes (Fabales) and possibilities of their control]. Prog. Plant Prot./Post. Ochr. Roślin 53 (4): 762-767.

Jerzak M.A., Czerwińska-Kayzer D., Florek J., Śmiglak-Krajewska M. 2012. Determinanty produkcji roślin strączkowych jako alternatywnego źródła białka - w ramach nowego obszaru polityki rolnej w Polsce. Rocz. Nauk Rol., Seria. G, 99 (1): 113-120.

Kolasińska K., Wiewióra K. 2002. Wpływ zawartości tanin w nasionach bobiku Vicia faba L. na zdolność kiełkowania, wigor, zdrowotność i plon nasion. Biul. IHAR 221: 235-251.

Księżak J. 2007. Dynamika przyrostu masy i akumulacja azotu przez odmiany bobiku o zróżnicowanej budowie morfologicznej. Ann. UMCS, Sec. E, 62 (1): 189-200.

Księżak J., Kuś J. 2005. Plonowanie bobiku w różnych systemach produkcji roślinnej. Ann. UMCS, Sec. E, 60: 195-205.

Kulig B., Pisulewska E., Sajdak A. 2007. Wpływ ilości wysiewu na plonowanie oraz wielkość powierzchni asymilacyjnej wybranych odmian bobiku. Zesz. Probl. Post. Nauk Rol. 522: 263-270.

Kulig B., Oleksy A., Kołodziejczyk M., Lorenc-Kozik A., Frąk P., Sikora A. 2012. Plonowanie oraz kształtowanie się składowych plonu i powierzchni asymilacyjnej łanu wybranych odmian bobiku w zależności od sposobu ochrony roślin. Fragm. Agron. 29 (4): 95-105.

Kulig B., Oleksy A., Sajdak A. 2009. Plonowanie wybranych odmian bobiku w zależności od sposobu ochrony roślin i gęstości siewu. Fragm. Agron. 26 (3): 93-101.

Kulig B., Ropek D., Dłużniewska J. 2006. Efektywność ekonomiczna i produkcyjna zabiegów ochrony roślin w uprawie zróżnicowanych morfologicznie odmian bobiku. Pam. Puł. 142: 251-262.

Kulig B., Zając T. 2007. Biologiczne i agrotechniczne uwarunkowania produkcyjności bobiku. Post. Nauk Rol. 1: 63-80.

Kurowski T.P., Hruszka M., Bogucka B. 2006. Zdrowotność bobiku w zależności od jego udziału w płodozmianie i stosowania wsiewki gorczycy sarepskiej. [The influence of stubble crops on health status of winter rye in simplified crop rotations]. Prog. Plant Prot./Post. Ochr. Roślin 46 (2): 24-30.

Marks M., Kurowski T.P., Orzech K., Kurowska A. 2004. Stan sanitarny łanu i plonowanie bobiku w zależności od sposobu uprawy roli. Fragm. Agron. 2 (82): 71-79.

Podleśny J. 2006. Przydatność siewu punktowego w uprawie wybranych gatunków roślin strączkowych. Inż. Rol. 13: 385-392.

Podleśny J. 2009. Wpływ ilości i rozkładu opadów w okresie wegetacji na wzrost, rozwój i plonowanie samokończących i tradycyjnych odmian bobiku. Acta Agrophys. 14 (2): 413-425.

Prusiński J. 2007. Content and balance of nitrogen in Faba bean fertilized with ammonium nitrate and fed additionally with urea. Electron. J. Pol. Agricul. Un. 10 (4), \#24. http://www.ejpau.media.pl/volume10/issue4/abs-24.html

Prusiński J., Borowska M., Kaszkowiak E. 2008. Wybrane wskaźniki produkcyjności roślin bobiku w warunkach wzrastającego nawożenia azotem. Biul. IHAR 248: 105-116.

Stępnik K., Lepiarczyk A. 2009. Wpływ warunków pogodowych i systemów uprawy roli na produkcyjność bobiku (Vicia faba ssp. minor L). Fragm. Agron. 26 (1): 127-135. 